\title{
The Sustainable Use of Outer Space: Complications and Legal Challenges to the Peaceful Uses and Benefit of Humankind
}

\author{
Mohammad Saiful Islam ${ }^{1,2}$ \\ ${ }^{1}$ School of Law, Beijing Institute of Technology, Beijing, China \\ ${ }^{2}$ Department of Law, International Islamic University Chittagong, Chittagong, Bangladesh \\ Email: saiful@law.iiuc.ac.bd
}

How to cite this paper: Islam, M. S. (2018). The Sustainable Use of Outer Space: Complications and Legal Challenges to the Peaceful Uses and Benefit of Humankind. Beijing Law Review, 9, 235-254. https://doi.org/10.4236/blr.2018.92016

Received: May 3, 2018

Accepted: June 9, 2018

Published: June 12, 2018

Copyright $\odot 2018$ by author and Scientific Research Publishing Inc. This work is licensed under the Creative Commons Attribution International License (CC BY 4.0).

http://creativecommons.org/licenses/by/4.0/

\section{c) (i) Open Access}

\begin{abstract}
All over the world space applications are considered as vital tools for carrying development in respect of social, economic and environment. The major space faring country grows their economy, science, technology, security through the use of space. Predominantly, events for economic growth through space exploration have considered noteworthy in the international arena. An uninterrupted increase of space activities indicates that space law and policies have become significant for a large number of countries. However, increasing the space faring nations, commercialization by the public, private entities and privation of political willingness of influential countries also denote the new concern to the peaceful use of space, maintaining space safety, security and sustainability. The existing legal protection towards the peaceful and sustainable uses of space is not measured satisfactorily well-organized and competent. Particularly, the issue of commercialization of space is not well agreed. The goal of this paper is to examine the shortcomings of present regimes and legal challenges to the sustainable use of space with identifying that there is an urgent necessity for effective and more comprehensive regime not just at the international level, but also at the national level.
\end{abstract}

\section{Keywords}

Space Law, Outer Space, Commercialization, Sustainable Use, Space Safety

\section{Introduction}

The universe is delighted by the human being and all belongings of creation in the universe for the benefit of humankind. Space is an enormous territory into 
which the human improved physically and intellectually. Scholar said, "This expansion has not only the potential to enhance the human condition, but also the power to transform it radically" (Noichim, 2005). Consequently, nowadays space is a part of our daily life. From a more specialized approach, space has opened exclusively new doors for all types of commercial, industrial, and scientific enterprises, ranging from agriculture, astronomy, communications, environmental protection, fishery, the prospecting for and conservation of natural resources, medical and pharmaceutical research, as well as diverse manufacturing processes relying on a gravity-free environment (Cheng, 1997). As a sovereign country, involvement in the space activity is a great prestige, honor, and means of making position before the world community. The peaceful uses of outer space are a powerful tool for the welfare of humanity and to the security of the Earth's environment.

The current situation of use of outer space is so competitive to the public and private sectors as well to attain potential benefits in the economic and political field. This aspect indicates that the importance and complexity of space use are increasing to national security and in social, economic and environmental development. From the one side, the increasing of space faring nations, use of outer space by public and private sectors, from the other side, the use of outer space through effective means, environmentally sound as well as use for commercial purposes is a new great challenge to the international community today. Moreover, space law's simplicity is challenged by the growing, each and every day, different technology as like as newfangled aspect to use of outer space. Another important undertaking is an upholding sustainable use of space for economic, social and environmental development, basically for developing countries. This stressed by general assembly resolution indicated that "The general assembly of UN stresses the importance of promoting effective means of using space technology to assist in the solution of problems of regional or global significance and of strengthening the capabilities of Member States, in particular developing countries, to use the applications of space research for economic, social and cultural development" (United Nations, 2000). The objectives of this research are to make fertile events of present complications of outer space law; to identify the national and international challenges to sustainable uses of outer space; and to attempt to accumulate urgently required development of outer space for peacefully gaining the potential benefits for humankind.

\section{Sustainable Use of Outer Space}

All nations have the non-exclusive rights to use and explore outer space. According to The Outer Space Treaty, the use of outer space shall be carried out for the benefit and in the interests of all mankind without discrimination. ${ }^{1}$ (Outer Space Treaty, 1967). The use of outer space in a peaceful means turn into the ${ }^{1}$ Article I of "Treaty on Principles Governing the Activities of States in the Exploration and Use of Outer Space, including the Moon and Other Celestial Bodies" 1967 [hereinafter "The Outer Space Treaty"]. 
highest concern of maximum "space scientists, lawyers, and practitioners" (Zhao, 2004). Perfectly, space activities must be carried out rationally, to the interests of humankind, maintaining international peace and security and to promote international co-operation. The treaty remarks in Article III, "States Parties to the Treaty shall carry on activities in the exploration and use of outer space, including the moon and other celestial bodies, in accordance with international law, including the charter of the United Nations, in the interest of maintaining international peace and security and promoting international co-operation and understanding" (Outer Space Treaty, 1967).

For the sustainable use of outer space, the peaceful use of space is maintained as the common basic principle of international space law (Fountain, 2002). The term "peaceful purposes" is a controversial one. Two explanations are mentioned: The first is that "peaceful purposes" means "non-aggressive". The second is that "peaceful purposes" meant "non-military". "Peaceful purposes" also mean the prohibition of specific weapons in open space. This includes nuclear weapons and weapons of mass destruction similar to atomic, biological and chemical weapons. Some military activities are permitted that include scientific research, peaceful purposes, using equipment and facilities that are necessary to carry out scientific and peaceful activities, and some activities are prohibited that include military bases, installations, fortifications, weapons testing and maneuvers (Gabrynowicz \& Serrao, 2004). It is challenging that peaceful purpose might put an end to through more commercialization of space. The world community should be measured specific attention to illegal activities and events, such as terrorist activities, that might be carried out in the name of commercialization (Zhao, 2004).

\section{Complications of Outer Space Law}

The United Nations Committee on the Peaceful Uses of Outer Space (UNCOPUOS) is the forum for the development of international space law. Beginning with international space law, the committee has established five international treaties and five sets of legal principles in space-related activities that are currently in force (Gabrynowicz, 2004). These treaties deal with matters of non-appropriation of outer space by one country, arms control, liability for damage by space objects, the rescue of spacecraft and astronauts, the avoidance of harmful activities with the environment, the registration of space objects etc. Each of the treaties strains the view that benefits from outer space should be engaged in enhancing the welfare of all countries and humankind (UNOOSA, 2016). There are a series of legal principles adopted by the United Nations General Assembly. Every set of legal principles has variable weight in international law (Gabrynowicz \& Serrao, 2004). In the future, the outer space exploration and development will not take place in a cooperative and peaceful means, for the reason that, space is a great potential field and outer space exploration and development is considered a competitive environment that makes a probability for 
interstate conflict for the following shortcomings and the non-existence of appropriate legal regimes.

\subsection{Appropriation of Outer Space}

Article II of The Outer Space Treaty refers no nation can make territorial claims to outer space and other celestial bodies. Each nation has freedom of access for conduct scientific investigation in space (Listner, 2003). This article simply forbids the national appropriation of outer space and the celestial bodies, this prohibition does not cover the possibility of an individual or private entities lawfully adopting any part of outer space (Pop, 2000).

\subsection{Prevention of Arms in Space}

Article IV of The Outer Space Treaty delivers regarding prevention of nuclear weapons and weapons of mass destruction. It is important to make sure that, outer space will not a background to an arms competition. But nowadays warfare is unthinkable without the support of space capabilities. Such as during the "Gulf War", the United States used satellites to include scouting, timing, position, communications, and weather information to execute attacks with an accuracy and timing not become before in human history (Butterworth, 2012). The provisions of this article only explicitly prohibit nuclear weapons and WMD, while ballistic missile armed is consciously out of this qualification (Reynolds \& Merges, 1989). It does not specifically address the placement of non-nuclear weapons, devices or those that are not capable of causing mass destruction (Listner, 2003). Moreover, the prohibition of article IV does not apply to conventional weapons and military satellite (Hobe, 2009). This article designates for a fractional prohibition of arms only (Hasselmann, 1983). Existing law doesn't cover the exclusive prevention of arms in outer space. Another thing is that no specific indications to a combination of "freedom of use" of space and "conclusive sovereignty" of the state. If any country run satellite in space for spying or collecting information of another country, then affected country has the right to protect this activity under the sovereignty. Some country achieved competence of combat on the terrestrial based weapon to take action against a satellite in space. However, this article does not cover prohibition of Anti-satellite weapons (ASAT) (Hobe, 2009). In 2007 the Chinese launched a ballistic missile armed to destroy a defunct Fengyun-1C weather satellite in low earth orbit (Kan, 2007). The United States demonstrated an ASAT capability ancillary to its anti-ballistic missile program on February 21, 2008 (Listner, 2011).

\subsection{Ambiguity of "Military Uses"}

Military use is considering a key portion of space activities since the commencement of the space age (Hobe, 2009). For upholding space security, in general, military activities are prohibited in outer space. Article IV of The Outer Space Treaty provides, "The establishment of military bases, installations, and 
fortifications, the testing of any type of weapons and the conduct of military maneuvers on celestial bodies shall be forbidden. The use of military personnel for scientific research or for any other peaceful purposes shall not be prohibited" (Outer Space Treaty, 1967). This article is ordinarily considered as the central point concerning with the military uses of space in the outer space treaty. But, as a whole, the article does not make available any clear definition of "military uses" or "peaceful uses" (Hobe, 2009). Moreover, the article fails to provide a wide-ranging regime covering all phases of the military uses of outer space (Hobe, 2009).

\subsection{Uncertainty of Meaning}

Many unintentional uncertainties also remain in the treaty, including the exact meaning of "nuclear weapon" "space weapon" and "weapon of mass destruction" as well as "peaceful uses" (Reynolds \& Merges, 1989). The normal meaning of "weapon of mass destruction" is more difficult to measure (Hobe, 2009). Treaty states "the moon and other celestial bodies are to be used exclusively for peaceful purposes" but not include outer space itself (Reynolds \& Merges, 1989). In the event of international space law, only terms are not vague, but the enforcement provisions and mechanisms are also uncertain. Furthermore, the absence of the binding force of principles is a question of great attention because the obligation is not same as that of an international convention (Bouvet, 2004).

\subsection{Provisions of Benefits Sharing}

The Outer Space Treaty provides some form of benefit sharing. ${ }^{2}$ The treaty states that outer space is the province of all mankind and exploration shall be carried out for benefit of all nations. ${ }^{3}$ But it does not arrange the establishment of an international body to share benefits and natural resources, nor does it assurance their preservation for future generations (Johnson, 2010).

\subsection{No Regimes for the Space Environment}

Article IX of The Outer Space Treaty requires launching States to preserve the environment of outer space in the matter of its space activities. However, there is no follow-on treaty to further define that responsibility or the role that orbital space debris plays (Listner, 2011). No legally binding treaty addresses space debris and protection of the space environment as like as the earth environment through using outer space. The United Nations makes the Space Debris Mitigation Guidelines that have no legal binding under international law, but States are encouraged to take actions to ensure that the guidelines are applied (Listner, 2011).

${ }^{2}$ The term "Benefit sharing" is a confusing one. Outer space treaty mentions space exploration shall be carried out for benefit of all nations, but did not certainly specify what type of benefit and how to benefit will share?

${ }^{3}$ Article I of The Outer Space Treaty. 


\subsection{No Framework of Commercial Activities}

Despite the fact, no theoretical framework can be decided to govern the commercial activities in outer space. In excess of any technical challenge, the nonexistence of legal stability is the prime weakness in the commercial development of outer space (Twibell, 1997). The present space law does not deliver guidance, facilitating the creation of an active regime fostering commercial space exploitation (Keefe, 1995). Nevertheless, even with the rickety legal standing in place, various parties, foreknowing potential profit, have started their own projects directing in commercializing outer space (Manzione, 2002). Without clear-cut rules and systems in place, the activities are carried out that is more and more injurious to the development of commercial activities in outer space (Zhao, 2004).

\subsection{Evading Human Rights Provisions}

All space activities for the benefit of mankind; space exploration also conducted by human beings, astronauts visit space, stay in space for scientific experiment and accomplish space task. Simultaneously, through space tourism persons travel for entertaining, leisure or business purposes. But no single provision of human rights to protect the human being engaged with space. It is general, where is a human being, there is a human right, it's not confined by territory.

\subsection{Morally Weak the Moon Treaty}

The four treaties were concluded and came into force significantly from 1967-1974. The final and most controversial child of the Outer Space Treaty is the Moon Treaty (Listner, 2011) approved in 1979 with nominal support and maximum disagreement (Gabrynowicz, 2004). It is the only foundational treaty that has not been ratified by the main space faring countries like the United States, the Russian Federation (USSR) and the People's Republic of China. The signatories of the Moon Treaty don't hold an equal or better space capability than non-signatories.

\subsection{Drawbacks in the NPS Principles}

As a focal document, in 1992 the UN General Assembly unanimously approved the Principles Relevant to the Use of Nuclear Power Sources in Outer Space (NPS Principles). However, principles do not have a binding force, it's a non-binding legal document. The NPS Principles are significant for providing a "detailed safety assessment, a re-entry notification process, responsibility and liability mechanisms and assistance to States" (Bouvet, 2004). One of the major drawbacks of the NPS Principles is the deficiency of textual mention of all the NPS used in outer space. For example, limits related to the use of uranium are defined, but there are no detailed specifications (Bouvet, 2004). Finally, International space laws have shortcoming from the various view of point. Ultimately altogether, it is a great matter of intelligent that major space faring countries did 
not ratify all treaties and more or less other countries raise the question of the effectiveness of present laws.

\section{Challenges to Sustainable Use of Outer Space}

\subsection{Provide Technological Support and Sharing Information to Developing Nations}

All nations have free access to all areas of space and the celestial bodies on the basis of equality. Therefore, all nations have equal right to use and explore space (Johnson, 2010). Article I of The Outer Space Treaty establish that all nations are permitted to explore and use outer space on the basis of equality and without discrimination. Exploration and use must be for the benefit of all countries, irrespective of their degree of economic or scientific development (Outer Space Treaty, 1967). Article IX provides, state parties shall conduct to balance the interests of exploring countries and developing countries. Article II of the Outer Space Treaty provides that, "[O]uter space, including the moon and other celestial bodies, is not subject to national appropriation by claim of sovereignty, by means of use or occupation, or by any other means" (Outer Space Treaty, 1967). Transfer of technology to developing countries should not be mandatory (Zhao, 2004). Modern technology characterizes valuable assets that must be similarly protected by the present laws of intellectual property rights. "The entities, having worked, risked, and spent money on research and development, should be allowed to maintain their technologies and retain any profits from them" (Hoover, 1983). Developing nations should achieve technology at market price, but the price should be fair and rational. Other ways can be framed to promote the transfer of technology to developing nations, such as establishing of joint endeavors with developing countries (Zhao, 2004), or can be through "participation method" that, developing nations could provide the intelligent person and the developed country will provide the technology. Furthermore, as a sense of balance to benefit the exploring entities and States, rules about economic support to developing countries, particularly to those having been really affected by the commercial activities in outer space, should be formulated (Zhao, 2004).

\subsection{Ensure the Rights of Future Generations in Outer Space}

Sustainable development is the establishing principle for achieving present human needs without damaging the demands of future generations maintaining integrity and constancy of the natural systems. The modern idea of sustainable development is derived from the Brundtland Report in 1987. Generally considered in modern application and exploration of outer space, fundamental elements are the area must be dedicated to peaceful purposes; and the area must be preserved for future generations (Heim, 1990). It is an indispensable and inordinate challenge to confirm uphold the healthy environment and make sure development without destroying the rights of future generations in space. Article IX of The Outer Space Treaty provided, in the exploration and use of outer 
space, States should pursue studies and conduct exploration of outer space so as to avoid harmful contamination and also adverse changes in the environment of the Earth (Outer Space Treaty, 1967). The issues of what constitutes harmful contamination in Earth's environment have yet to be interpreted. The legal definition of "adverse" and "harmful" will also modification as Earth, indigenous sciences progress, separately or in concert, with the planetary exploration space sciences (Robinson, 2005). As a result of multifaceted political, economic, scientific, technological, educational, and other global problems, there has been practicing exclusively only international cooperation for sustainable space development among the developed countries (Noichim, 2005). The space faring nations should promote a supportive environment for peaceful and sustainable use of space, decrease environmental effects on Earth and protect the terrestrial environment. We should escape a regime that will ultimately reflect the over-exploitation of resources and environmental havoc (Fountain, 2002).

\subsection{Proper Use of Nuclear Power Sources}

In respect to advancement and development of space activities, among the significant priorities, nuclear sources are using considerably to accomplish space operation that more operative from existing sources of energy (Bouvet, 2004). For future space activities, nuclear power sources have been branded as a vital technology and substantial budget apportionments are calculated towards their development. Since 1961 more than fifty space missions through nuclear energy have been launched (Bouvet, 2004). Universally the appropriate use of nuclear power is a great threat for the new world; although, the international community tries to control it's expansion and misapplications. The use of nuclear energy has various risks "for space missions, from the time of the launch, through the injection into orbit, and during the life of the spacecraft around the Earth, or during its trip into deep space" (Bouvet, 2004). For instance, famous Cosmos 954 case of 1978, a Soviet satellite, which entered in Canadian area and Soviet Craft Cosmos 1402, in a second accident, radioactivity was spread in the high atmosphere over the ocean. Both of the cases proved an integral amount of risk. In 1986 two conventions were adopted under the International Atomic Energy Agency (IAEA). "The goal of these Conventions is to minimize the consequences of the accident, protect life, property and the environment from the effects of radioactive releases" (Bouvet, 2004). In 1992 the UN General Assembly unanimously approved the Principles Relevant to the Use of Nuclear Power Sources in Outer

${ }^{4}$ A. See The Convention on Early Notification of a Nuclear Accident (Notification Convention), Date of adoption: 26 September 1986, Date of entry into force: 27 October 1986, available at https://www.iaea.org/publications/documents/treaties/convention-early-notification-nuclear-accide nt (last visited April 15, 2017).

B. See The Convention on Assistance in the Case of a Nuclear Accident or Radiological Emergency (Assistance Convention), Date of adoption: 26 September 1986, Date of entry into force: 26 February 1987, available at

https://www.iaea.org/publications/documents/treaties/convention-assistance-case-nuclear-accidentor-radiological-emergency (last visited April 15, 2017). 
Space (NPS Principles). The followings are challenges for the use of NPS in legal arena; advance notification of the use of NPS in outer space, launching States shall ensure that comprehensive safety assessment is conducted prior to the launch, safety methods need to be undoubtedly well-defined at the national level and make sure the safety requirements, mechanisms shall particularly have demarcated to confirm the highest level of safety, develop exact provisions on the protection of astronauts, discovery, protecting legal mechanisms and substitute technology development relating to the use of NPS in outer space (Bouvet, 2004). Scholar suggests that, bearing in mind the inherent risks in the use of NPS the use of nuclear power sources should be restricted to space missions that cannot be reasonably operated by non-nuclear energy sources (Bouvet, 2004). In outer space, the use of nuclear power sources is a great challenging and important matter, hence, it is time to reach a particular treaty and promote future developments of both technical and legal area by examining the greatest attention and responsibility to avoid all possible risks.

\subsection{Implementation of Existing Space Laws}

Adoption of space law treaties and principles at the international level is a foremost landmark in the development of the first era of international space law. Space law treaties and principles arrange a set of rules to ensure the peaceful and sustainable uses of outer space. In the matter of raising space faring nations, implementation of the existing space law is also an abundant challenge. Moreover, some major space faring countries did not ratify some of the treaty and more or less other countries raise the question of the effectiveness of present laws. About the advance notification of space activities, Article XI of the Outer Space Treaty provides, appropriately notify conducting space activities by the space faring State to the United Nations as well as the public together with nature, locations, conduct, general function of the space object and results of such activities (Outer Space Treaty, 1967). The world is now perceiving multiplayer space power, control the use of nuclear weapons and other kinds of weapons in space is excessive undertaking. Article IV delivers, "States Parties to the Treaty undertake not to place in orbit around the earth any objects carrying nuclear weapons or any other kinds of weapons of mass destruction, install such weapons on celestial bodies, or station such weapons in outer space in any other manner" (Outer Space Treaty, 1967). This article is one of the most significant provisions on arms control is accompanied by other treaties of arms control. Commercialization of space is widely spread issue in outer space activities and major space faring nations like the U.S. highly promoted commercialization by private and non-governmental sectors. Appropriate administration, supervision and control are a vigorous concern for absent of international and national appropriate law. Article VI of the Outer Space Treaty provides that, the activities of non-governmental entities in outer space shall require authorization and provide continuing supervision by way of national legislation or any other means in or- 
der to ensure that national activities were carried out in conformity with the provisions of the outer space treaty (Outer Space Treaty, 1967). Preserve environmental balance by decrease adversarial environmental changes. Harmful contamination through the extra environmental matter of the celestial bodies could introduce adverse environmental changes. Article 7.1 of the Moon Agreement states that "States' Parties shall take measures to prevent the disruption of the existing environmental balance" ("Moon Agreement", 1979). Article IX of the Outer Space Treaty is required in the exploration and use of outer space "to avoid [its] harmful contamination". Regarding "the environment of the Earth" treaty required to "avoid adverse changes... resulting from the introduction of extraterrestrial matter and, where necessary shall adopt appropriate measures for this purpose" (Outer Space Treaty, 1967).

\subsection{Uphold International Cooperation and Responsibility}

The term "cooperation" includes "action of cooperating or acting jointly with another or other" (Campbell, 1990). Cooperation must comprise obligations of each of the parties to enter into action so as to achieve a definite goal (Wolfrum, 1986). Therefore, international cooperation is the obligation of States to cooperate with each other. It is important to remind that, in spite of intelligence and capacity, humans cannot shine in space activities without coordination and cooperation. This thought is designated in the following quote: "No longer can nations, or people, live in isolation. They must come together in education and global (space) cooperation" (UNISPACE-III, 1999). The concept of international cooperation is a key principle of international law articulated as a significant purpose of the UN in UN Charter. Article 1(3) of the UN Charter mentions, "To achieve international co-operation in solving international problems of an economic, social, cultural, or humanitarian character..." ("UN Charter", 1945). The main objective of international cooperation is not only to uphold the benefits of all those States engaged in efficiently working together on a specific action but also to promote the development of developing countries as well (United Nations, 1970). With concern for the imminent benefit and the interests of all humankind, "States shall be guided by the principle of international cooperation in the peaceful exploration and use of outer space" (Noichim, 2005). Article IX of the Outer Space Treaty provides that, States shall be guided by the principle of cooperation and mutual assistance and shall conduct all their activities with due regard to the corresponding interests of all other States (Outer Space Treaty, 1967). The principle of international cooperation is a crucial element in the exploration and sustainable utilization of outer space (Haanappel \& Airspace, 1987). This principle is well-maintained not simply in all outer space treaties and the five groups of legal principles but also in those United Nation General Assembly resolutions associated with outer space activities (Noichim, 2005). Moreover, from the commencement of the space era, the world community has acknowledged the great significance of international cooperation in the explora- 
tion and sustainable use of outer space for peaceful purposes (Nations, 1958). International law is the outcome of power, cooperation, negotiation and the finest implementation method is cooperation among the countries. Therefore, international space cooperation is leading ingredients for space safety, to sustainable use and to receive benefits for all humankind. Undoubtedly, larger welfare and benefits from space can be originated by increasing international cooperation. Fruitful cooperation is threatening for increasing space nations, "demands for private property rights on the Moon and other celestial bodies," (Galloway, 2004) and power politics of the world where one group agrees to other group disagree.

"Responsibility" has not been collectively understood in any legal treaty relating to outer space. This, however, does not mean that State responsibility is not applicable to the duties of States' law as, in international relations, the incursion of a right or other legal interest of one subject of the law by another unavoidably generates legal responsibility (Abeyratne, 1997). International responsibility comprises both to breaches of treaty provisions and other breaches of legal obligation. All rights of an international nature include international responsibility. With reference to Article VI of the Outer Space Treaty, the concept of "international responsibility" was broader than "state responsibility" comprised all acts and not only wrongful acts (Assembly, 2003). According to the terms of the Treaty, nations have international responsibility and liability of proper supervision for all public and private space activities. This article mentions that States bear international responsibility for national activities in outer space carried on by governmental agencies or by non-governmental entities. The activities of non-governmental entities shall require authorization and continuing supervision by the appropriate State Party to the treaty (Outer Space Treaty, 1967). It includes liability for any damages instigated by a space object on Earth or to another State's property in the course of any space activity (Listner, 2003). In 2010 U.S. space policy places larger highlighting on "international cooperation and building a global sense of responsibility for sustaining the space environment for use by all and for peaceful purposes through the enhancement of Transparency and Confidence Building Mechanisms (TCBMs)" (Gibbs, 2009).

\subsection{Improve the Domestic Law and Policy}

In the 21st century, the world observed the emergence of the new groups of spacefaring nations. Henceforth, the space community has acknowledged that newly active and raising space faring nations have need of expertise and guidance to develop their national space law and legal institutes (Gabrynowicz, 2004). The United States is one of the few countries that constantly generate comprehensive national space policies to reflect a particular administration's position (Gibbs, 2009). As a key spacefaring country, the U.S. has developed their domestic space law. The objectives of The National Aeronautics and Space Act ${ }^{5}$ National Aeronautics and Space Act of 1958, 42 U.S.C. $\$ 2451$, Enacted by the 85th United States Congress, Effective July 29, 1958. 
of $1958^{5}$ are the enlargement of human knowledge of space, ensure prospective benefits from the peaceful use of space and the promotion of international cooperation for the peaceful application of the results ("National Aeronautics and Space Act", 1958). Other particular space laws approved by Congress for the purposes of remote sensing systems run public and private satellite communications and "to promote economic growth and entrepreneurial activity by using space for peaceful purposes" (Gabrynowicz, 2004). A new national space policy authorized by the U.S. President on June 28, 2010, and it changed US space policy in numerous fundamental aspects (States, 2010). The policy comprises commercial, civil and national security sector guidelines. It also includes some clarity on the particular roles and responsibilities of the space-related agencies and departments. This supersedes the Bush Administration policy issued in August 2006 (Gibbs, 2009).

Europe is one of the major players in the space field and in order to strengthen its position and capacities, European Space Agency has developed an overall European Space Strategy (United Nations, 2002). The purpose of ESA mentioned in Article II "The purpose of the Agency shall be to provide for and to promote, for the exclusively peaceful purposes, cooperation among the European States in space research and technology and their space applications, with a view to their being used for scientific purposes and for operational space applications systems" (ESA, 1975). China started space activities from 1956 (LI, 2012), and in the most recent few years has made speedy developments in space exploration, technologies and space activities, now hastening to establish basic infrastructure in outer space; including communication, remote sensing and navigation, nevertheless, "it still lags behind in the legal arena" (Zhao, 2015). There is no national legislation only orders and regulatory documents, two ministerial regulations $^{6}$ are straight relating to space matter activities (LI, 2012). To guarantee the activities of outer space for peaceful purposes and to promote the further advancement of space events, China should get faster its national space legislation process in accordance with international laws, particularly International Space Laws. In respect of the new enactment of space law, they can seek out the legislative knowledge and experience of other countries (LI, 2012). Simultaneously, should incorporate and codify the present regulations and other regulatory documents (LI, 2012). The China National Space Administration (CNSA) said, China always abides the international space law and is building excessive efforts to introduce particular laws in 2020. CNSA mention that "the country has already made policies and regulations in the administration of civil space launch, registration of space objects, reduction and prevention of space debris" (Xinhua, 2014). The UN illustrious about the inevitability of establishing and developing ${ }^{6}$ i. the Measures for the Administration of Registration of Objects Launched into Outer Space, Order No. 6 of the Commission of Science, Technology, and Industry for National Defense and the Ministry of Foreign Affairs of the People's Republic of China, 8 February 2001. ii. the Interim Measures on the Administration of Licensing the Project of Launching Civil Space Objects, Order No. 12 of the Commission of Science, Technology, and Industry for National Defense of the People's Republic of China, 21 November 2002. 
appropriate domestic law: "The need for effective laws and policies on space activities, not just at the international level, but also at the national level, has become clear to the increasing number of States now actively involved in the field of space. The successful operation of space law, policies and institutions in a country relies on the presence of suitable professionals" (UNOOSA, 2003).

\subsection{Space Debris and Environment Protection}

The fragmentation of debris in orbit is originated from payloads and from rocket bodies. The growth of space activity has created a genuine junkyard of orbital space debris comprising of defunct satellites, expended rocket boosters, components and tools lost during extravehicular activities by astronauts and cosmonauts (Listner, 2011). Debris mainly populates the area of near-earth space below $2000 \mathrm{~km}$ where many application satellites reside and where all manned operations take place (Menter, 1989). Maximum space mission creates some amount of space debris. Space debris carriages a significant, constant and undiscriminating threat to all spacecraft, irrespective of the nation or entity to which they belong (Index, 2011). The amount of orbital debris continues to increase, particularly in Low Earth Orbit (LEO) (Index, 2011). The deterioration of the outer space environment, particularly the space debris, has been broadly acknowledged as the most important threat to the sustainability of space activities. Therefore, provisions regarding control of debris in outer space are important matters before international lawmakers. In January 2007, a Chinese anti-satellite test that destroyed one of its own decommissioned weather satellites generated a huge amount of space debris and condemned by the international community with respect to long-term space sustainability (Gibbs, 2009). This missile test generated a subsequent debris field of around 3000 pieces which remain to threaten human missions and satellites operating in this orbital plane (Martin, 2015). Moreover, in 2008 U.S. destruction of the failed USA-193 satellite and in 2009 collision between a Russian and a U.S. satellite has assisted to underline the necessity for effective measures to curb the creation of space debris (Index, 2011). Besides, increase awareness of space debris threats, nonstop efforts to development and implementation of international measures to tackle the problem. Spacefaring states; including China, Japan, Russia and the U.S., as well as the European Union (EU) have technologically advanced debris mitigation standards and the United Nations (UN) have approved voluntary guidelines (Index, 2011). The removal process, the problems produced by such debris, mechanism, and technology to remove debris from outer space are debatable. The international community needs to regulate universally recognized guidelines and recommendations for the effective control of debris from the outer space activities.

\subsection{Incorporation of Civil and Military Uses in Space Missions}

Incorporation of military and civil tasks in space activities are new challenges for the peaceful use of outer space. Although making a detachment of military and 
civil space activities is a fundamental precept of the domestic law of a number of spacefaring nations (Gabrynowicz, 2004). For instance, NASA was established to provide civilian oversight of The United States space program (NASA, 2008). The U.S. space program determined that space events would not generate a national discrepancy and engaged the national space program transferring from the Defense Department to NASA as under civil control by settling "all space-related civilian personnel, functions, facilities, equipment, records, property and funds not primarily related to military operations and weapon system development" (Gabrynowicz, 2004). However, The United States has dominated the military space arena since the end of the Cold War and continues to give priority to its military and intelligence programs, which are now integrated into virtually all aspects of military operations (Index, 2016). By the convention of ESA, the purpose of the European space agency is legally restricted to "exclusively peaceful purposes" which has mostly been understood to exclude military activity (ESA, 1975). The integration of the two sectors has long been a reality for some nations and a more recent trend for others (Gabrynowicz, 2004). China does not maintain a strong separation between civil and military applications, but its program is widely believed to provide support to the military (Index, 2016). The close cooperation between the civil and military space segments is predominantly evident in Russia, China, France, and in recent times, Germany and Japan. Present day, other countries in Asia, as well as Europe are increasing cooperation between their civil and military space sectors (Gibbs, 2009).

\subsection{Further Development of International Space Law}

Space law is clearly challenged by the expanding and complex context of space uses and in the space environment (Gabrynowicz, 2004). In this stage space faring nations are raising, time is changeable and new issue arises; including commercialization, intellectual property in outer space, cybercrime, new technology and newfangled dimensions of weapons. Simultaneously, private and public engagements in space are required to further development of space law. Whereas the first phase of space law development accomplished in 1979 through five treaties. The challenges before world to generate new space laws with harmonizing sovereignty to establish property rights, provisions of space as province of all humankind, the role of non-spacefaring nations to use of outer space, appropriate regulation for private and public sectors in outer space (Gabrynowicz, 2004), and applicable guide to control space environment as like as the earth environment through using outer space.

For peaceful and sustainable use of space with international cooperation, the international community should be reached new sets of rules for space use. All the established and newly-active space faring nations come to an understanding that a new phase of space law development has been started. Both developing and developed countries recognize the significance of a stable regime adopting for the exploration and sustainable use of outer space (Webber, 1982). They 
recognize that there is a necessity to develop common legal rules and principles or standards mainly for technological change and increase of the commercialization of space (UNCOPUOS, 2001b). However, there are different opinions as to the best approach to be taken to direct the development procedure (Gabrynowicz \& Serrao, 2004). Some countries consider these provisions are inadequate and beyond the development through amendment, they suggest a new comprehensive treaty should be negotiated (UNOOSA, 2001). They argue that a new treaty is the only rational way to meet the necessities of space activities for the reason that countries are not participating in the existing treaties owing to the uncertain of treaty terms (UNCOPUOS, 2001a). Other countries opinion that present legal regimes are adequate and consider as a foundation for further development. Their attitude about the amendment or expansion of the current treaties (UNCOPUOS, 2002). For further development of new wide-ranging treaty should take careful consideration of what can be lost or what can be gained, limitations, challenges or difficulties of existing space law (Gabrynowicz \& Serrao, 2004).

\subsection{Regulate and Control the Commercial Activities}

Outer space is chock-full of natural resources and the production possible profits from the use of these resources rationalize commercializing of outer space (Zhao, 2004). Hence, commercialization of space is now a well-known topic in space activities through combined public and private sector. Commercial activities in space are more dependable with the period of globalization. Moreover, the commercialization of space is an increasingly large and important part of social, economic and information infrastructure. However, space laws are perpendicular in front of new challenged, by the growth of new environment of public-private international space commercialization. Recognizing the commercial prospects of outer space is a subject in need of urgent resolution. It is significant and challenges to formulate a legal regime for the exploitation of outer space by attainment a balance between generating, protecting the profits of relevant exploiting bodies and serving the interests of humankind (Tan, 2000). The developed country considers this a great matter of economic development. The U.S. declares space policy to "encouraging and facilitating a growing entrepreneurial U.S. commercial space sector" and "... the use of U.S. commercial space capabilities to the maximum practical extent, consistent with national security" (Giacalone, 2011). A fundamental goal will be to "enable a dynamic, globally competitive commercial space sector in order to promote innovation, strengthen U.S. leadership, and protect national, homeland, and economic security" (Giacalone, 2011). In the nonexistence of certain property rules and an enforcement mechanism with appropriate authority, there is likely to be pandemonium in the commercialization of outer space (Webber, 1982). The interlocking of public and private context purposes in space activities now is a part of space law's subject that will continue to necessitate further development (Gabrynowicz, 2004), 
together with a particular regulation both in the level of international and national as well. Because the existing regime is insufficient to address the grave legal questions arising from commercialization of space. The commercialization of outer space is no extensively a fantasy. There is an urgent necessity to take a practical look at the issue and formulate feasible rules and organs to protect against taking the wrong direction (Zhao, 2004). Accordingly, some scholars have correctly recommended that it is staged for scientists, engineers, lawyers and management experts to develop a practical set of guidelines for space commercialization (Cheng, 1991).

\section{Propositions for Sustainable use of Space}

\subsection{Eliminate the Nebulous of Arms and Military use}

It is important to ascertain the use of non-nuclear weapons, devices or those that are not capable of causing mass destruction, the engagement of conventional weapons, use of ballistic missile armed. Determine perfect definition of "nuclear weapon", "weapon of mass destruction", "military uses", "peaceful uses" and provide a wide-ranging regime covering all phases of the military uses of outer space. Not only the moon and other celestial bodies are to be used for peaceful purposes, but also necessary to ensure the peaceful use of outer space itself.

\subsection{Establishment of International Body}

The international community should establishment of an international body as space authority to regulate and control all space activities, including confirm sharing of benefits, appropriate exploitation of natural resources and ensure guarantee to the preservation of resources for future generations. Simultaneously, make effort to providing technology, sharing information and benefits to the developing countries. The specific body can formulate by the holding following possible names, like International Space Authority (ISA), or World Space Organization (WSO) or International Space Agency $(I S A)$, or International Space Organization $(I S O)$, or Organization for world Space Affairs (OWSA) etc.

\subsection{New Regime for Space Environment and Commercialization}

It is an appropriate demand of time enact follow-on new regime and organ to define the role and responsibility of space faring country for protecting the space environment, mitigation space debris and to control the commercial activities in space. In respect of the environment, United Nations Environment Program (UNEP) can play the role to protect the environment by confirming supervision and imposing recompense. To control and regulate the commercial activities a subcommittee may form and a committee will regulate the commercial activities in space.

\subsection{Provisions for Asteroid Exploitation}

The moon treaty is ratified by nominal states and non-signatory countries are 
more powerful than signatories. At present time the moon is a vital potential field for exploration of resources to many countries like USA, China, South Korea and European space agency. They have planned and tried to make a moon village. In this context, the International community shall have the responsibility to generate completely new and conclusive regime with getting parties of all space power country for asteroid exploitation.

\subsection{Establish Enforcement Mechanism and Space Court}

In the international space law enforcement provisions and mechanisms are uncertain. Hence, should regulate the specific mechanism for enforcement of the law and it is also well required establish space court for dispute settlement among the space faring nations. It can be by the name of like International Space Court (ISC) or International Tribunal for Space Law (ITSL) or International Court for Space Activities (ICSA) and World Space Court (WSC) etc.

\subsection{Urgent Development of Space Law}

Improvement of space law is compulsory in domestic level and international level as well. Each space faring country and thus nations have the concentration to run space activities should abide and constitute appropriate national legislation, the space agency to make sure space safety, sustainable and peaceful uses of space. It is mandate of time to develop international space law in respect of harmonizing sovereignty to establish property rights, provisions of space as province of all humankind, proper use of nuclear power sources, commercialization of space, the role of non-spacefaring nations to use of outer space, appropriate regulation of private and public sectors in outer space.

\section{Conclusion}

This is the great opportunity to use space as a platform to increase the benefits in the field of economic, social and environmental development. The use of space application is a fundamental tool for conveying development throughout the world. The core important matters to ensure the sustainable use of space and to promote the developing countries to get benefits from space activities are international cooperation and attitude of good faith towards implementing, regulating the space law in the exploration and peaceful uses of outer space. This reaffirmed by the general assembly resolution stated "Reaffirming the importance of international cooperation in the exploration and peaceful uses of outer space" (UNOOSA, 2016). Necessity of well-organized laws and policies on space activities has become stronger by the increasing number of space faring states and for other tangible challenges. Scholar says that, the challenge lying ahead is to generate the appropriate legal regime that will support and inspire the exploration (Zhao, 2004). The ultimate target of exploration of space is to develop the human being and confirm their better life and facility. So, each spacefaring country should maintain and make sure they guarantee that all activities will be for the 
peaceful use and for humanity which solely depends on the good faith, mutual cooperation, respect to other interest and equality, and ensure equitable participation of space benefits as well. In this context, to ensure sustainable uses of outer space, the actual problem is not only the law itself. The genuine challenge is making the political determination to address the law. Therefore, international community needs to regulate a set of new rules and principles of their political will which is difficult but not impossible.

\section{References}

Abeyratne, R. (1997). The Use of Nuclear Power Sources in Outer Space and Its Effect on Environmental Protection. Journal of Space Law, 25, 17.

Assembly, U. N. G. (2003). Report on the United Nations/Republic of Korea Workshop on Space Law on the Theme "United Nations Treaties on Outer Space: Actions at the National Level”. http://www.unoosa.org/pdf/reports/ac105/AC105_814E.pdf

Bouvet, I. (2004). Use of Nuclear Power Sources in Outer Space: Key Technology Legal Challenges. Journal of Space Law, 30, 203.

Butterworth, R. L. (2012). Space and the Joint Fight. Paper Presented at the Strategic Forum.

Campbell, H. (1990). Black's Law Dictionary. St. Paul, MN: West Publishing Co.

Cheng, B. (1991). The Commercial Development of Space: The Need for New Treaties. Journal of Space Law, 19, 17.

Cheng, B. (1997). Studies in International Space Law. Oxford: Clarendon Press.

ESA (1975). The Convention for the Establishment of a European Space Agency (ESA).

Fountain, L. M. (2002). Creating Momentum in Space: Ending the Paralysis Produced by the Common Heritage of Mankind Doctrine. Connecticut Law Review, 35, 1753-1787.

Gabrynowicz, J. I. (2004). Space Law: Its Cold War Origins and Challenges in the Era of Globalization. Suffolk University Law Review, 37, 1041-1065.

Gabrynowicz, J. I., \& Serrao, J. E. (2004). An Introduction to Space Law for Decision Makers. Journal of Space Law, 30, 227.

Galloway, E. (2004). Maintaining International Space Cooperation for Peaceful Uses. Journal of Space Law, 30, 311-315.

Giacalone, J. A. (2011). Global Trends in the Commercialization of Space. Journal of Business \& Economics Research, 6, 65-76. https://doi.org/10.19030/jber.v6i8.2462

Gibbs, G. (2009). An Analysis of the Space Policies of the Major Space Faring Nations and Selected Emerging Space Faring Nations. Annals of Air and Space Law, 37, 279-332.

Haanappel, P., \& Airspace, O. S. (1987). Co-Operation between Canada and the United States in Civilian Space Activities. Annals of Air and Space Law, 3, 235.

Hasselmann, C.-G. (1983). Weapons of Mass Destruction, Article IV Outer Space Treaty and the Relationship to General Disarmament. In 25th Colloquium of the Law of Outer Space (pp. 99-111). New York: American Institute of Aeronautics and Astronautics.

Heim, B. E. (1990). Exploring the Last Frontiers for Mineral Resources: A Comparison of International Law Regarding the Deep Seabed, Outer Space, and Antarctica. Vanderbilt Journal of Transnational Law, 23, 819-849.

Hobe, S. (2009). Cologne Commentary on Space Law: In Three Volumes. Köln: Carl Heymanns Verlag. 
Hoover, R. K. (1983). Law and Security in Outer Space from the Viewpoint of Private Industry. Journal of Space Law, 11, 115.

Index, S. S. (2011). Space Security 2011 Executive Summary. http://spacesecurityindex.org/wp-content/uploads/2014/10/executive.summary.2011re vised.PDFversion.pdf

Index, S. S. (2016). Space Security Index 2016: Executive Summary. http://spacesecurityindex.org/wp-content/uploads/2016/10/SSI-2016-Executive-Summ ary.pdf

Johnson, D. (2010). Limits on the Giant Leap for Mankind: Legal Ambiguities of Extraterrestrial Resource Extraction. American University International Law Review, 26, 1477.

Kan, S. (2007). China's Anti-Satellite Weapon Test.

Keefe, H. (1995). Making the Final Frontier Feasible: A Critical Look at the Current Body of Outer Space Law. Santa Clara Computer \& High Technology Law Journal, 11, 345-371.

Li, J. (2012). China's Space Law and Regulation. https://swfound.org/media/95017/li-china_space_law_regulation-nov2012.pdf

Listner, M. J. (2003). The Ownership and Exploitation of Outer Space: A Look at Foundational Law and Future Legal Challenges to Current Claims. Regent Journal of International Law, 1, 75.

Listner, M. J. (2011). International Space Law: An Overview of Law and Issues. New Hampshire Bar Journal, 62-71.

Manzione, L. L. (2002). Multinational Investment in the Space Station: An Outer Space Model for International Cooperation. American University International Law Review, 18, 507-535.

Martin, D. (2015). The Battle Above. http://www.cbsnews.com/news/rare-look-at-space-command-satellite-defense-60-min utes/

Menter, M. (1989). Environmental Implications and Responsibility in the Use of Outer Space. Journal of Space Law, 17, 69.

Moon Agreement (1979). Agreement Governing the Activities of States on the Moon and Other Celestial Bodies.

NASA (2008). National Aeronautics and Space Act of 1958. http://history.nasa.gov/spaceact-legishistory.pdf

National Aeronautics and Space Act (1958). National Aeronautics and Space Administration (NASA). Pub. L. No. 85-568 \$102 (c).

Noichim, C. (2005). International Cooperation for Sustainable Space Development. Journal of Space Law, 31, 315-338.

Outer Space Treaty (1967). Treaty on Principles Governing the Activities of States in the Exploration and Use of Outer Space, Including the Moon and Other Celestial Bodies. 18 U.S.T. 2410, 610 U.N.T.S. 205.

Pop, V. (2000). Appropriation in Outer Space: The Relationship between Land Ownership and Sovereignty on the Celestial Bodies. Space Policy, 16, 275-282. https://doi.org/10.1016/S0265-9646(00)00037-0

Reynolds, G. H., \& Merges, R. P. (1989). Outer Space: Problems of Law and Policy. Boulder, CO: Westview Press.

Robinson, G. S. (2005). Interplanetary Contamination: The Ultimate Challenge for Envi- 
ronmental and Constitutional Lawyers. Journal of Space Law, 31, 117-163.

States, U. (2010). National Space Policy of the United States of America (Policy). https://www.nasa.gov/sites/default/files/national_space_policy_6-28-10.pdf

Tan, D. (2000). Towards a New Regime for the Protection of Outer Space as the Province of All Mankind. Yale Journal of International Law, 25, 145-194.

The Charter of the United Nations (UN Charter) (1945). Chapter I: Purposes and Principles, Article 1.

Twibell, T. S. (1997). Circumnavigating International Space Law. ILSA Journal of International and Comparative Law, 4, 259.

UNCOPUOS (2001a). Committee on the Peaceful Uses of Outer Space Legal Subcommittee. http://www.unoosa.org/pdf/reports/transcripts/legal/LEGALT_640E.pdf

UNCOPUOS (2001b). Committee on the Peaceful Uses of Outer Space, Legal Subcommittee. http://www.unoosa.org/pdf/reports/transcripts/legal/LEGALT_641E.pdf

UNCOPUOS (2002). Report of the Committee on the Peaceful Uses of Outer Space. http://www.unoosa.org/pdf/gadocs/A_57_20E.pdf

UNISPACE-III (1999). Space Science and Microgravity Research and Their Benefits (Report). http://www.unoosa.org/pdf/reports/unispace/ACONF184_6E.pdf

United Nations (1958). Question of the Peaceful Use of Outer Space (General Assembly Resolution). RES/1348 (XIII). http://www.unoosa.org/pdf/gares/ARES_13_1348E.pdf

United Nations (1970). Declaration on Principles of International Law Concerning Friendly Relations and Co-Operation among States in Accordance with the Charter of the United Nations. Resolution Adopted by the General Assembly, A/RES/25/2625. http://www.un-documents.net/a25r2625.htm

United Nations (2000). Third United Nations Conference on the Exploration and Peaceful Uses of Outer Space.

United Nations (2002). Importance of Space Technology for Sustainable Development among Issues Highlighted, as Fourth Committee Takes up Peaceful Uses of Outer Space. http://www.un.org/press/en/2002/gaspd239.doc.htm

UNOOSA (2001). Report of the Legal Subcommittee on Its Fortieth Session. http://www.unoosa.org/oosa/oosadoc/data/documents/2001/aac.105/aac.105763_0.html

UNOOSA (2003). United Nations/Republic of Korea Workshop on Space Law "United Nations Treaties on Outer Space: Actions at the National Level". http://www.unoosa.org/oosa/en/ourwork/spacelaw/workshops/index.html

UNOOSA (2016). Space Law Treaties and Principles. http://www.unoosa.org/oosa/en/ourwork/spacelaw/treaties.html

Webber, A. D. (1982). Extraterrestrial Law on the Final Frontier: A Regime to Govern the Development of Celestial Body Resources. Georgetown Law Journal, 71, 1427-1456.

Wolfrum, R. (1986). International Law of Cooperation: Encyclopedia of Public International Law (Vol. 9, pp. 193-198). Max Planck Institute for Comparative Public Law and International Law.

Xinhua (2014). China Expects to Introduce Space Law around 2020. China Daily. http://www.chinadaily.com.cn/china/2014-11/17/content_18930721.htm

Zhao, Y. (2004). An International Space Authority: A Governance Model for a Space Commercialization Regime. Journal of Space Law, 30, 277-296.

Zhao, Y. (2015). National Space Law in China: An Overview of the Current Situation and Outlook for the Future. Hotei Publishing. 